\title{
PENERAPAN PEMBELAJARAN MODEL JIGSAW UNTUK MENINGKATKAN MINAT DAN HASIL BELAJAR FISIKA
}

\author{
Muhammad Luqman Hakim Abbas \\ Tadris Fisika, Institut Agama Islam Negeri Tulungagung \\ *Email: mluqman.abbas@gmail.com
}

DOI: http://dx.doi.org/10.29303/jpft.v5i2.1409

\begin{abstract}
This research is a classroom action research which aims to improve learning outcomes physics class in Madrasah Aliyah Al-Ihsan Kalijaring. The sample used in this research is class XI MIPA totaling 31 people, by applying science technology society learning model. This study is successful if students achieve learning outcomes classical completeness $85 \%$ with the value of each student reach $\geq 75$. Based on the evaluation of the obtained value of the average grade in the first cycle of 77.01 with $74.42 \%$ classical completeness. In the second cycle learning outcomes of students has increased, with an average grade of 93.02 and classical completeness amounted to $90.46 \%$. Based on the interest questionnaire that has been distributed to students before and after the action, data is obtained that the student's interest has increased. The indicators that showed an increase were the total score obtained before the administration of action was 1842 with an average of 42.84 increasing to 2326 with an average of 54.86. Based on the results of the study it can be concluded that by applying the Jigsaw cooperative learning model can increase interest and learning outcomes in physics class XI MIPA Madrasah Aliyah Al-Ihsan Kalijaring Tembelang Jombang.
\end{abstract}

Keywords : jigsaw; interest in learning; learning outcomes

\section{PENDAHULUAN}

Kualitas pendidikan dimasa sekarang harus terus menerus ditingkatkan, berbagai macam cara di ujicobakan untuk dapat meningkatkan kualitas pendidikan. Hal ini tidak lepas dari penilaian proses pembelajaran yang belum optimal. Fakta yang terjadi di sekolah pada saat ini menunjukkan, sebagian siswa belum berhasil menguasai pemahaman konsep fisika maupun aplikasi konsep fisika seharihari (Fauzi, 2011). Permasalahan itu muncul akibat tingkat penguasaan belajar siswa sebatas hafalan saja (Lestari et al. 2017). Hafalan ini hanya terbatas pada hafalan tekstual dari buku teks atau catatan yang diperoleh selama proses belajar mengajar berlangsung (Yenni, 2016).

Berdasarkan hasil observasi pendahuluan di kelas XI MIPA MA AlIhsan Kalijaring Tembelang Jombang yang dilaksanakan pada bulan Juli-Agustus 2019 terhadap proses pembelajaran fisika di peroleh bahwa minat dan hasil belajar siswa fisika relatif rendah. Indikator-indikator yang menunjukkan rendahnya minat dan hasil belajar fisika rendah adalah: (1) siswa kurang persiapan pada saat akan mengikuti pelajaran yang ditunjukkan dengan terlambatnya kehadiran siswa dalam kelas pada saat pelajaran akan dimulai dan adanya sebagian siswa yang tidak memiliki buku penunjang yang cukup (Nopiani et al. 2017), (2) siswa mengganggu temannya yang mendengarkan pelajaran yang disampaikan oleh guru (Munandar et al. 2018), (3) siswa membolos pada saat pelajaran berlangsung, (4) siswa tidak mengerjakan tugas atau terlambat mengumpulkan tugas yang diberikan oleh guru, (5) guru cenderung lebih aktif daripada siswa, sehingga siswa tidak dapat terlibat secara langsung dalam proses pembelajaran (Nopiani et al., 2017), (6) nilai rata-rata ulangan harian mata pelajaran fisika siswa kelas XI MIPA relatif masih rendah, di mana nilai rata-rata untuk mata pelajaran fisika siswa adalah 70,0.

Hasil observasi menunjukkan bahwa rendahnya minat dan hasil belajar siswa Madrasah Aliyah Al-Ihsan Kalijaring 
disebabkan oleh penggunaan metode pengajaran yang kurang tepat, sehingga menyebabkan siswa tidak menyukai mata pelajaran yang disampaikan oleh guru. Guru msih sering menggunakan metode ceramah, yang mengakibatkan siswa menjadi kurang aktif dalam menemukan konsep-konsep fisika (Lestari et al., 2017). Konsep fisika akan lebih mudah difahami jika siswa dapat memahaminya sendiri dengan cara bekerja sama diantara mereka dengan guru sebagai fasilitator (Kusdiastuti et al. 2019).

Seorang guru khususnya guru fisika yang baik harus berusaha membimbing, mengarahkan, dan menciptakan kondisi belajar siswa (Susilawani et al. 2019). Namun dalam kenyataannya pembelajaran yang dilakukan masih sebatas penyampaian secara searah dari guru ke siswa sehingga siswa menjadi kurang aktif dalam pembelajaran (Af'idah, 2016). Untuk mencapai ketuntasan belajar fisika siswa, guru harus berusaha untuk mengubah metode yang telah digunakan yaitu metode ceramah dengan metode yang dapat melibatkan siswa secara aktif (Nurhikmah et al. 2018). Hal ini perlu dilakukan mengingat dalam pembelajaran fisika siswa tidak hanya dituntut untuk sekedar memahami konsepkonsep fisika (Abbas, 2016), tetapi juga harus dapat menyumbangkan kreativitas, keterampilan, dan sikap ilmiah dalam menyelesaikan masalah (Munandar et al. 2018).

Salah satu metode pembelajaran yang melibatkan siswa secara aktif adalah pembelajaran kooperatif. Pembelajaran kooperatif merupakan pembelajaran yang menekankan pada semangat kerja sama (gotong royong), sehingga dapat dikatakan sebagai pembelajaran gotong royong (Sasono, 2014). Adapun falsafah yang mendasari pembelajaran kooperatif atau pembelajaran gotong royong tersebut adalah falsafah homo homini socius (Yenni, 2016). Pada dasarnya, manusia merupakan mahluk sosial yang selalu saling membutuhkan satu sama lainnya sehingga dengan pembelajaran kooperatif ini akan melatih para peserta didik untuk memahami pentingnya arti sebuah kerja sama bagi kelangsungan hidup (Nopiani et al. 2017). Tanpa kerja sama manusia tidak akan bisa hidup, bahkan tanpa kerja sama mungkin kehidupan ini sudah punah. Beberapa metode pembelajaran kooperatif tersebut adalah "STAD (Student Teams-achievement Devision), TGT (Teams-Games-Tournament), jigsaw II, TAI (Team Accelerated Instruction), CIRC (Cooperative Integrated Reading \& Composition), GI (Group Investigation), Learning Together, Complex Instruction, dan Structured Dyadic Methods" (Sasono, 2014).

Pembelajaran kooperatif, siswa dituntut untuk membangun pengetahuan sendiri secara aktif (Fauzi, 2011). Dalam hal ini siswa didorong untuk mengaktifkan struktur kognitifnya untuk membangun sendiri pengetahuan yang baru, selain itu siswa dapat berinteraksi dengan temantemannya untuk menyelesaikan permasalahan yang dihadapi dalam memahami materi pelajaran yang sedang dipelajari (Irawati, 2014). Dengan demikian diharapkan ada simbiosis mutualisme yang terjalin diantara siswa sehingga menyebabkan pengetahuan yang dipakai oleh salah seorang siswa dapat dipahami pula oleh semua siswa (Abbas, 2019a). Disini semua siswa harus berperan aktif dalam mencari dan mengungkapkan pendapatnya tentang suatu permasalahan.

Jigsaw merupakan salah satu model pembelajaran kooperatif yang dapat diterapkan dalam kelas yang heterogen (Palennari, 2011). Pembelajaran kooperatif model jigsaw ini juga efektif untuk meningkatkan minat dan hasil belajar fisika (Ningsih, 2014). Kelebihan dari model pembelajaran kooperatif model jigsaw ini adalah cara yang efisien dalam menarik 
perhatian siswa mempelajari suatu materi pelajaran (Af'idah, 2016). Proses belajar jigsaw mendorong untuk mendengarkan, menyepakati, dan bertanggung jawab dengan memberi setiap anggota dari kelompok bagian yang penting untuk dibahas dalam aktivitas akademik (Abbas, 2019).Setiap anggota dari kelompok harus bekerja bersama sebagai team untuk mencapai tujuan bersama, sehingga tiap siswa akan tergantung kepada siswa yang lainnya.

Berdasarkan uraian di atas, maka sebagai upaya meningkatkan minat dan hasil belajar fisika siswa, dilakukan penelitian dengan judul: "Penerapan Pembelajaran Kooperatif Model Jigsaw Untuk Meningkatkan Minat Dan Hasil Belajar Fisika".

\section{METODE PENELITIAN}

Jenis penelitian ini adalah penelitian tindakan kelas. Penelitian ini dilakukan oleh guru dikelasnya sendiri melalui refleksi diri dengan tujuan untuk memperbaiki kinerjanya sehingga nantinya dapat meningkatkan hasil belajar siswa (Rochiati Wiriaatmadja, 2019). Dalam penelitian ini guru bukanlah satu-satunya peneliti, tetapi ada orang lain yang terlibat dan mereka dalah satu tim yang mempunyai kedudukan yang sama. Jadi dalam penelitian ini peneliti berkolaborasi dengan guru, peneliti terlibat secara langsung dalam proses penelitian. Tugas peneliti yaitu mengamati, merekam, merefleksi dan mengevaluasi kegiatan pembelajaran.

Penelitian ini dilaksanakan di MA Al-Ihsan Kalijaring Tembelang Jombang. Subjek penelitian ini adalah siswa kelas XIMIPA yang berjumlah 31 orang yang terdiri dari 9 siswa laki-laki dan 22 siswa perempuan. Pemilihan kelas XI-MIPA sebagai subjek penelitian disebabkan karena kelas ini mempunyai tingkat heterogenitas yang paling tinggi ditinjau dari segi minat dan hasil belajarnya. Sumber data dalam penelitian ini adalah guru fisika, siswa, dan peneliti. Peneliti sebagai pemberi tindakan, siswa sebagai subjek penelitian, dan guru fisika sebagai pengamat aktivitas yang terjadi selama berlangsungnya proses pembelajaran. Data yang diperoleh dari penelitian ini terdiri dari data yang bersifat kualitatif dan kuantitatif.

Data yang bersifat kualitatif terdiri dari angket minat belajar, hasil observasi dan keterampilan kooperatif siswa, catatan lapangan, dan hasil wawancara. Minat belajar fisika siswa diukur dengan menggunakan angket. Angket minat belajar fisika siswa ini diberikan dua kali, yaitu pada awal kegiatan (sebelum pembelajaran kooperatif model jigsaw) dan pada akhir kegiatan pada siklus terakhir. Tes hasil belajar meliputi tes akhir pada akhir perlakuan pada masing-masing bab. Tes akhir diberikan pada akhir tindakan setiap siklus. Hasil tes ini digunakan untuk mengetahui peningkatan pemahaman penguasaan siswa terhadap materi yang telah dipelajari setelah diberikan tindakan, yaitu pembelajaran kooperatif model jigsaw. Untuk mengetahui aktivitas siswa selama kegiatan pembelajaran berlangsung, diadakan pengamatan atau observasi yang dilakukan oleh tiga orang pengamat (Borg \& Gall, 1989). Data hasil observasi dicatat dalam lembar observasi. Catatan lapangan digunakan untuk merekam data yang tidak terekam dalam lembar observasi mengenai hal-hal yang terjadi selama pemberian tindakan, yang meliputi suasana kelas, aktivitas guru, dan aktivitas siswa. Wawancara dilakukan untuk memperoleh masukan dari siswa mengenai kegiatan pembelajaran yang telah diberikan sebelumnya, apakah mereka mengalami kesulitan dalam memahami materi pelajaran, apakah mereka mengalami kesulitan dalam belajar dengan anggota kelompoknya, bagaimana pola kerja dan peran siswa dalam 
kelompoknya. Wawancara juga dimaksudkan untuk lebih memperjelas adanya peningkatan sikap dan minat belajar fisika siswa setelah penerapan pembelajaran kooperatif model jigsaw.

Analisis data dilakukan setiap kali tindakan dalam satu siklus berakhir. Untuk menentukan adanya peningkatan minat belajar fisika siswa, maka skor angket minat belajar siswa sebelum pemberian tindakan dibandingkan dengan skor angket minat belajar siswa setelah pemberian tindakan (Rochiati Wiriaatmadja, 2019). Sedangkan untuk menentukan minat belajar fisika siswa tergolong sangat baik, baik, cukup baik, rendah, atau sangat rendah digunakan kategori berjenjang (ordinal) mengacu pada model distribusi normal. Untuk menentukan ada tidaknya peningkatan hasil belajar siswa, maka skor tes setiap kali tindakan dalam satu siklus berakhir dibandingkan dengan skor tes pada siklus berikutnya. Perubahan yang terjadi selanjutnya dinyatakan dalam bentuk persentase ketuntasan belajar secara klasikal.

Tahap-tahap penelitian yang pertama observasi awal bertujuan untuk menentukan masalah yang dianggap penting. Langkah yang dilakukan meliputi penentuan mitra peneliti yaitu guru bidang studi dan wawancara dengan guru dan beberapa siswa tersebut tentang metode atau pendekatan pembelajaran yang sering digunakan, prestasi belajar siswa dan perilaku siswa selama kegiatan belajar-mengajar di kelas. Dari hasil observasi awal maka dilakukan refleksi awal dan diperoleh bahwa kegiatan belajar mengajar masih menggunakan metode ceramah dan pembelajaran yang berpusat pada guru, sehingga siswa kurang diberdayakan. Atas dasar data tersebut, peneliti memberiakan tindakan berupa penerapan metode pembelajaran kooperatif model jigsaw untuk memperbaikinya. Metode pembelajaran kooperatif model jigsaw ini dilaksanakan melalui dua siklus.
Pada siklus pertama dilakukan rencana tindakan I berupa metode pembelajaran kooperatif model jigsaw. Sebelum sebelum pelaksanaan tindakan tersebut peneliti merencanakan beberapa langkah yang akan dilaksanakan. Setelah itu dilakukan pelaksanaan tindakan I yang merupakan penerapan dari skenario pembelajaran dengan menggunakan metode pembelajaran kooperatif model jigsaw yang telah disusun dalam rencana tindakan I. langkah selanjutnya adalah observasi yang dilakukan dengan tujuan agar dapat memperoleh informasi yang lebih mendalam dan komprehensif tentang suasana pembelajaran mulai dari awal sampai akhir tindakan. Data hasil observasi tersebut digunakan untuk mengetahui kelemahankelemahan maupun kelebihan-kelebihan dari tindakan yang telah dilaksanakan, yang selanjutnya akan digunakan sebagai acuan untuk tindakan berikutnya (Af'idah, 2016). Hasil observasi dicatat dalam lembar observasi dan catatan lapangan. Kegiatan obervasi ini dilakukan bersamaan dengan pelaksanaan tindakan I.

Setelah menyelesaikan satu siklus, peneliti bersama dengan guru fisika melakukan diskusi guna membahas hasil observasi terhadap pelaksanaan tindakan. Dari hasil observasi dan diskusi tersebut selanjutnya dijadikan sebagai refleksi dalam rangka memperbaiki tindakan pada siklus berikutnya. Berdasarkan temuan peneliti setelah pemberian tindakan I diperoleh bahwa minat belajar siswa masih rendah. Hal ini ditunjukkan oleh aktivitas siswa selama proses belajar mengajar berlangsung antara lain: sebagian besar siswa masih pasif sehingga masih belum bisa aktif dan berpartisipasi dalam diskusi; terdapat siswa yang mengganggu temannya. Dari hasil tes akhir yang dilakukan pada akhir siklus ketuntasan belajar siswa masih relatif rendah. Jadi, dapat disimpulkan bahwa minat dan hasil belajar siswa masih perlu 
ditingkatkan lagi. Oleh karena itu, dilakukan perbaikan-perbaikan pada siklus selanjutnya.

Siklus kedua diawali dengan rencana tindakan II. Pada rencana tindakan II ini dilakukan perbaikan-perbaikan terhadap kekurangan-kekurangan yang terjadi di siklus I dan mempertahankan kelebihankelebihan yang ada. Tindakan II berupa metode pembelajaran kooperatif model jigsaw dengan beberapa perbaikan antara lain: (1) perbaikan LKS, (2) peningkatan kemampuan guru dalam mengelola kelas, memotivasi siswa, dan mengontrol pemahaman siswa, (3) perbaikan alokasi waktu. Setelah itu dilakukan pelaksanaan tindakan II yang merupakan penerapan dari skenario pembelajaran dengan menggunakan metode pembelajaran kooperatif model jigsaw yang telah disusun dalam rencana tindakan II. Langkah selanjutnya adalah observasi II yang dilakukan dengan tujuan agar dapat memperoleh informasi yang lebih mendalam dan komprehensif tentang suasana pembelajaran mulai dari awal sampai akhir tindakan. Data hasil observasi tersebut digunakan untuk mengetahui kelemahankelemahan maupun kelebihan-kelebihan dari tindakan yang telah dilaksanakan, yang selanjutnya akan digunakan sebagai acuan untuk tindakan berikutnya. Hasil observasi dicatat dalam lembar observasi dan catatan lapangan. Setelah data diperoleh maka dilakukan analisis dan refleksi II. Setelah menyelesaikan satu siklus, peneliti bersama dengan guru fisika melakukan diskusi guna membahas hasil observasi terhadap pelaksanaan tindakan. Dari hasil observasi dan diskusi tersebut selanjutnya dijadikan sebagai refleksi dalam rangka memperbaiki tindakan pada siklus berikutnya..

Data tentang sikap dan minat belajar dapat dicek dengan menggunakan teknik pemeriksaan keabsahan data. Teknik pengecekan keabsahan data yang digunakan dalam penelitian ini adalah teknik triangulasi dan ketekunan pengamatan (Borg \& Gall, 1989). Untuk data hasil belajar tidak dilakukan pengecekan keabsahan data karena keabsahannya dianggap sudah jelas. Teknik triangulasi yang digunakan dalam penelitian ini adalah teknik triangulasi dengan penyidik. Triangulasi dengan penyidik dilakukan dengan membandingkan data pengamatan yang diperoleh peneliti dengan hasil data pengamatan rekan peneliti.

\section{HASIL DAN PEMBAHASAN}

Penerapan metode pembelajaran kooperatif model jigsaw pada pembelajaran fisika kelas XI MIPA MA Al-Ihsan Kalijaring Tembelang Jombang meliputi 3 tahap, yaitu: (1) tahap pra instruksional; (2) tahap instruksional; dan (3) tahap evaluasi. Dalam pelakasanan siklus I, langkahlangkah tersebut telah dilaksanakan dan telah memberikan keunggulan, berupa kemudahan siswa dalam memahami materi pelajaran yang sedang dipelajari melalui diskusi kelompok belajar kooperatif dan memberikan kesempatan yang banyak kepada siswa untuk melakukan tanya jawab dengan anggota kelompoknya maupun dengan guru. Hal ini juga diperkuat dengan adanya peningkatan nilai dari nilai kuis yang telah diberikan guru terhadap nilai awal. Skor peningkatan yang dipoleh kelompok unggul adalah 28.33. Namun, dalam siklus ini terdapat beberapa kekurangan, antara lain: (1) siswa belum terbiasa dengan metode pembelajaran kooperatif model jigsaw sehingga dalam pelaksanaan diskusi kelompok membutuhkan waktu yang relatif lama, (2) partisipasi siswa dalam diskusi kelompok masih kurang nampak, (3) siswa tidak memanfatkan kesempatan yang ada untuk bertanya kepada temannya apabila terdapat kesulitan dalam memahami materi, dan (4) siswa masih kurang dalam penyampaian materi yang sudah dipahami kepada anggota kelompok yang lain. 
Ketuntasan belajar secara klasikal yang dicapai kelas XI MIPA adalah 77,01 dengan ketuntasan klasikal 74,42\%.

Berpijak dari permasalahan pada siklus I, maka dilaksanakan perbaikanperbaikan pada siklus II, perbaikan tersebut meliputi: perbaikan LKS: (1) perbaikan LKS, (2) perbaikan alokasi waktu, dan (3) meningkatkan kemampuan guru dalam mengelola kelas, mengontrol pemahaman siswa, dan memotivasi siswa. Pada siklus ini diperoleh beberapa kelebihan yang merupakan peningkatan dari proses pembelajaran yang dilakukan di siklus I. Kelebihan yang diperoleh yaitu: (1) respon siswa terhadap penjelasan guru yang dilakukan sebelum diskusi sudah baik, (2) banyak siswa yang bisa memberikan jawaban dari pertanyaan singkat yang diajukan guru, (3) siswa sudah bisa memahami sistem pembelajaran kooperatif model jigsaw, karena sudah melakukannya di siklus I, (4) banyak siswa berpartisipasi dalam diskusi kelompok ahli, (5) siswa dapat menjelaskan materi pembelajaran yang sudah dikuasainya pada saat diskusi kelompok asal, (6) interaksi siswa (tanya jawab) saat terjadi diskusi kelompok asal sudah baik, (7) siswa sudah cukup baik dalam menjawab kuis dan postes, (8) secara umum siswa dapat menjawab soal-soal kuis secara baik, sehingga banyak anggota kelompok yang memberikan sumbangan poin peningkatan kelompok walaupun skor peningkatan lebih rendah dibandingkan dengan siklus sebelumnya, (9) rata-rata poin peningkatan individu sebesar 20, dan (10) persentase ketuntasan belajar fisika yang telah tercapai dengan nilai rata-rata 93,02 dan ketuntasan klasikal sebesar 90,46\%. Namun, pada siklus II ini juga masih terdapat kekurangan. Kekurangan tersebut antara lain menurunnya skor peningkatan individu dan kelompok terdapat seorang siswa yang masih menggangu temannya pada saat diskusi walaupun guru sudah memberikan peringatan.

Berdasarkan angket minat yang telah disebarkan kepada siswa sebelum dan sesudah tindakan diperoleh data bahwa minat siswa mengalami peningkatan. Indikator-indikator yang menunjukkan peningkatan tersebut yaitu skor total yang diperoleh sebelum pemberian tindakan sebesar 1842 dengan rerata 42.84 meningkat menjadi 2326 dengan rerata 54.86. Dari angket yang telah disebarkan juga diperoleh seorang siswa memenuhi kriteria sangat kurang, 6 siswa memenuhi kriteria kurang, 21 siswa dengan kriteria cukup, dan 4 siswa memenuhi kriteria baik. Setelah pemberian tindakan mengalami peningkatan menjadi tidak seorangpun siswa yang memiliki kriteria sangat kurang, menurunnya jumlah siswa yang mendapat kriteria kurang menjadi tinggal 4 orang siswa, menurunnya jumlah siswa yang mendapat kriteria cukup menjadi tinggal 19 orang siswa, dan meningkatnya jumlah siswa yang memiliki kriteria baik menjadi 8 orang siswa.

Dalam penerapan metode pembelajaran kooperatif model jigsaw ini siswa semakin aktif dan semakin berminat dalam belajar fisika sehingga menimbulkan motivasi untuk belajar sehingga hasil belajar siswa meningkat. Kesimpulan tersebut sesuai dengan pendapat Af'idah (2016) yang menyatakan bahwa minat dapat mempengaruhi kualitas pencapaian hasil belajar siswa dalam bidang- bidang tertentu. Siswa juga terlatih dalam melakukan diskusi kelompok belajar kooperatif yang dilakukannya bersama temannya sehingga siswa dapat menemukan sendiri pengetahuan melalui interaksi dengan temannya. Peranan guru dalam pembelajaran ini hanya sebatas sebagai fasilisator, motivator, organisator, dan pengontrol jalannya proses belajar mengajar. Berdasarkan uraian diatas dapat disimpulkan bahwa penerapan metode pembelajaran 
kooperatif model jigsaw efektif dalam meningkatkan minat dan hasil belajar siswa kelas XI. Meningkatnya hasil belajar siswa setelah penerapan metode pembelajaran kooperatif model jigsaw ini juga didukung oleh penelitian yang telah dilakukan oleh Yenni Agustine Shovia Insany (2016) yang menyimpulkan bahwa pembelajaran kooperatif model jigsaw dapat meningkatkan hasil belajar siswa.

\section{PENUTUP}

Berdasarkan hasil penelitian yang telah dilakukan maka dapat diambil kesimpulal, pertama pembelajaran kooperatif model jigsaw efektif dapat meningkatkan minat belajar fisika siswa kelas XI MIPA MA Al-Ihsan Kalijaring tembelang Jombang. Kedua Pembelajaran kooperatif model jigsaw efektif dapat meningkatkan hasil belajar siswa kelas XI MIPA MA Al-Ihsan Kalijaring tembelang Jombang.

Berdasarkan simpulan penelitian tersebut, maka penulis dapat rumuskan saran sebagai berikut, bagi Pembaca dapat digunakan untuk meningkatkan pengetahuan dan pemahaman pembaca tentang metode pembelajaran fisika yang efektif dan efisien. Siswa juga terlatih dalam melakukan diskusi kelompok belajar kooperatif yang dilakukannya bersama temannya sehingga siswa dapat menemukan sendiri pengetahuan melalui interaksi dengan temannya. Bagi Institusi Pendidikan dapat digunakan sebagai model pembelajaran dengan metode yang sederhana dan mudah dipahami yaitu jigsaw. Sedangkan bagi peneliti selanjutnya dapat digunakan sebagai acuan dalam melakukan penelitian selanjutnya

\section{REFERENSI}

Abbas, M. L. H. 2016. Pengembangan Instrumen Three Tier Diagnostic Test Miskonsepsi Suhu dan Kalor. Ed-
Humanistics, 01, 83-92.

Abbas, M. L. H. 2019a. Identifikasi Miskonsepsi Mahasiswa Tadris Fisika Menggunakan Four Tier Diagnostic Test Pada Mata Kuliah Kalkulus II. Jurnal Matematika dan Pendidikan Matematika, 4(1), 7-16.

Abbas, M. L. H. 2019b. Penerapan Animasi Macromedia Flash Untuk Meningkatkan Hasil Belajar Fisika Pada Materi Tekanan. EdHumanistics : Jurnal Ilmu Pendidikan, 04(01).

Af'idah, N. 2016. Peningkatan Aktivitas dan Kemampuan Kognitif Mahasiswa Pendidikan IPA Angkatan 2015 Pada Perkuliahan Gelombang-Optik Melalui Cooperative Learning Tipe Jigsaw. Jurnal Pemikiran Penelitian Pendidikan dan Sains, 4(2), 117-132.

Borg, W. R., \& Gall, M. D. 1989. Educational Research An introduction. New York: Longman.

Fauzi, A. 2011. Pembelajaran Fisika Dengan Pendekatan Kooperatif Model Team Game Tournament(Tgt) Sebagai Upaya Peningkatan Kompetensi Sosial Mahasiswa. Jurnal Orbith, 07(3), 413417.

Irawati, I. 2014. Penerapan Metode Jigsaw Untuk Meningkatkan Motivasi Dan Prestasi Belajar Fisika Kelas Xii Man 15 Jakarta, (24), 89-93.

Kusdiastuti, M., Harjono, A., Gunawan, \& Nisyah, M. 2019. Respon Guru Dan Peserta Didik Terhadap Pembelajaran Fisika Dengan Model Inkuiri Terbimbing Dipadu Advance Organizer. Jurnal Pendidikan Fisika dan Teknologi, 1(1), 1-13.

Lestari, H., Ayub, S., \& Hikmawati, H. 2017. Penerapan Model Pembelajaran Sains Teknologi Masyarakat (STM) untuk Meningkatkan Hasil Belajar Fisika Siswa Kelas VIII SMPN 3 Mataram. Jurnal Pendidikan Fisika dan Teknologi, 2(3), 111.

Munandar, H., Sutrio, S., \& Taufik, M. 
2018. Pengaruh Model Pembelajaran Berbasis Masalah Berbantuan Media Animasi Terhadap Kemampuan Berpikir Kritis dan Hasil Belajar Fisika Siswa SMAN 5 Mataram Tahun Ajaran 2016/2017. Jurnal Pendidikan Fisika dan Teknologi, 4(1), 111.

Ningsih, D. S. 2014. Meningkatkan Prestasi Belajar Matematika Melalui Pembelajaran Kooperatif Tipe Jigsaw Pada Siswa Smk Negeri 3 Meulaboh Tahun 2013/2014. Jurnal Pendidikan Matematika, 1(1), 67-84.

Nopiani, R., Harjono, A., \& Hikmawati, H. 2017. Pengaruh Model Pembelajaran Advance Organizer Berbantuan Peta Konsep Terhadap Hasil Belajar Fisika Siswa Sma Negeri 1 Lingsar. Jurnal Pendidikan Fisika dan Teknologi, 3(2), 137.

Nurhikmah, Gunawan, \& Ayub, S. 2018. Pengaruh Model Pembelajaran Berbasis Masalah Berbantuan Simulation Based Laboratory (Sbl) Terhadap Hasil Belajar Fisika Peserta Didik Kelas Xi Ipa Sman 1 Montong Gading. Jurnal Pendidikan Fisika dan Teknologi, 4(2), 16-22.

Palennari, M. 2011. Potensi Strategi Integrasi $\mathrm{Pbl}$ dengan Pembelajaran Kooperatif Jigsaw dalam Meningkatkan Pemahaman Konsep Mahasiswa. Jurnal Ilmiah Pendidikan Biologi, Biologi Edukasi, 3(2), 16891699.

Rochiati Wiriaatmadja. 2019. Metode Penelitian Tindakan Kelas (2 ed.). Jakarta: PT Remaja Rosdakarya.

Sasono, M. 2014. Pengembangan Model Pembelajaran Kooperatif Jigsaw Yang Berorientasi pada Keterampilan Komunikasi Ilmiah Mahasiswa dalam Matakuliah Fisika Kuantum. Jurnal Edukasi Matematika dan Sains, 2(2), 1689-1699.

Susilawani, S., Doyan, A., \& Ayub, S. 2019. Perbedaan Keterampilan Generik Sains Antara Model Pembelajaran Berbasis Masalah Dengan Inkuiri Terbimbing
Ditinjau Dari Kemampuan Berpikir Kritis Siswa SMA. Jurnal Pendidikan Fisika dan Teknologi, 5(1), 16.

Yenni Agustine Shovia Insany. 2016. Pengaruh Model Pembelajaran Kooperatif Tipe Jigsaw terhadap Prestasi Belajar Siswa pada Pelajaran Fisika SMK. Jurnal Pemikiran Penelitian Pendidikan dan Sains, 7(2), 45-54. 